\title{
International Geoscience Collaboration to Support Critical Mineral Discovery
}
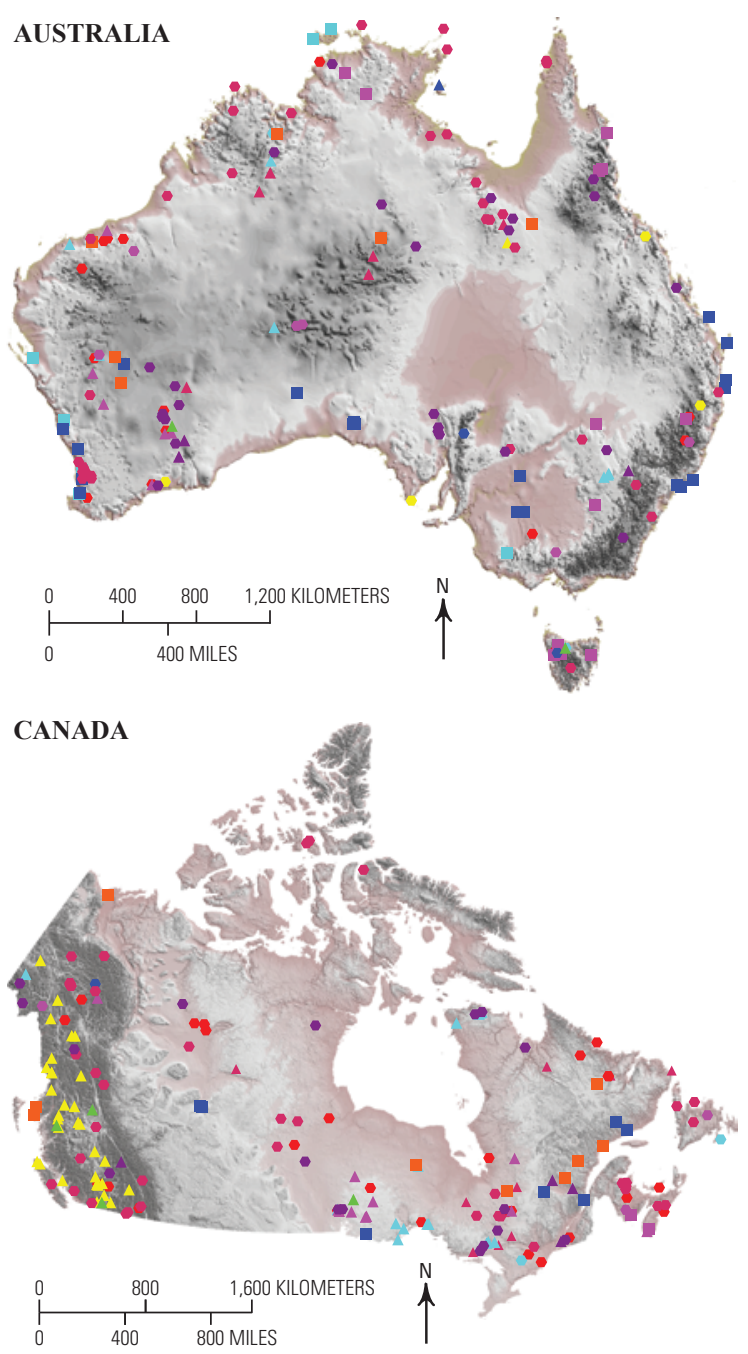

\section{Critical Minerals Mapping Initiative (CMMI) to Address Natural Resources Scarcity and Increase Reliable Supplies}

The importance of critical minerals and the need to expand and diversify critical mineral supply chains has been endorsed by the Federal governments of Australia, Canada, and the United States. The geoscience organizations of Geoscience Australia (GA), the Geological Survey of Canada (GSC) and the U.S. Geological Survey (USGS) have created the Critical Minerals Mapping Initiative (CMMI) to build a diversified critical minerals industry in Australia, Canada, and the United States by developing a better understanding of known critical mineral resources (fig. 1), determining geologic controls on critical mineral distribution for deposits currently producing byproducts (fig. 2), identifying new sources of supply through critical mineral potential mapping and quantitative mineral assessments, and promoting critical mineral discovery in all three countries.

\section{What Are Critical Minerals, and Why Are They Important?}

Critical minerals are natural resouces essential to the economic and national security of nations, and have the potential to become scarce because of geological, political, or technical factors. They are mineral commodities that have important uses and few effective substitutes (see Primary Uses of Critical Minerals sidebar). A mineral commodity that may have been considered critical 25 years ago may not be critical now, and one considered critical now may be less so in the future. Likewise, something not considered critical today may become critical in the future.

\section{Primary Uses of Critical Minerals}

- Cobalt: Rechargeable batteries and superalloys

- Gallium: Integrated circuits and optical devices like light-emitting diodes (LED)

- Germanium: Fiber optics and night vision applications

- Graphite: Major component of lithium-cobalt (Li-Co) oxide batteries

- Indium: Mostly used in liquid crystal display (LCD) screens

- Lithium: Primarily in batteries

- Niobium: Mostly in steel alloys

- Platinum Group Elements: Catalytic agents

- Rare Earth Elements: Batteries, electronics, magnets, communicaton, and medical technologies

- Rhenium: Lead-free gasoline or petrol and superalloys

- Tellurium: Steelmaking and solar cells I

\section{UNITED STATES}
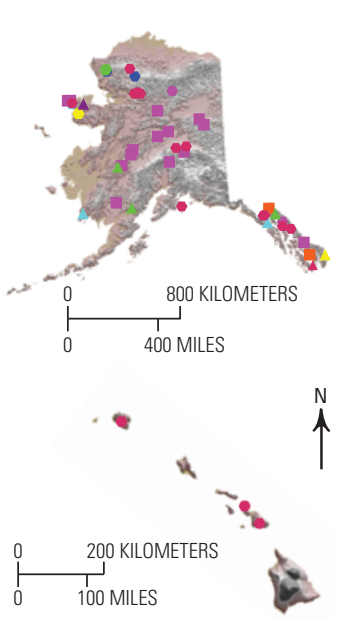

100 MILES

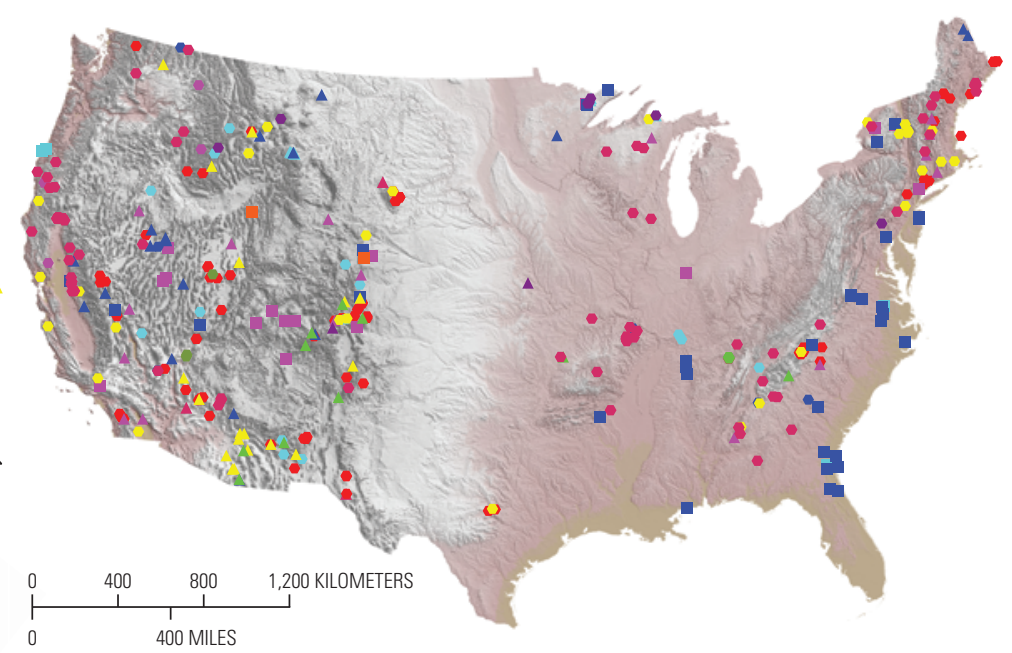

\section{EXPLANATION}

Critical Minerals

- Antimony $\triangle$ Manganese

- Barite $\quad$ Niobium and Tantalum

- Beryllium a Platinum Group Elements

- Cobalt $\triangle$ Rare Earth Elements

- Fluorite $\quad$ Rhenium

- Gallium a Tellurium

- Germanium घ Tin

- Graphite - Titanium

- Indium Vandium

$\Delta$ Lithium Zirconium

Figure 1. Critical mineral resources in Australia, Canada, and the United States (Labay and others, 2017). Critical minerals support a broad range of industrial sectors and a diversity of high-tech industries important to global economies (see Primary Uses of Critical Minerals sidebar). 


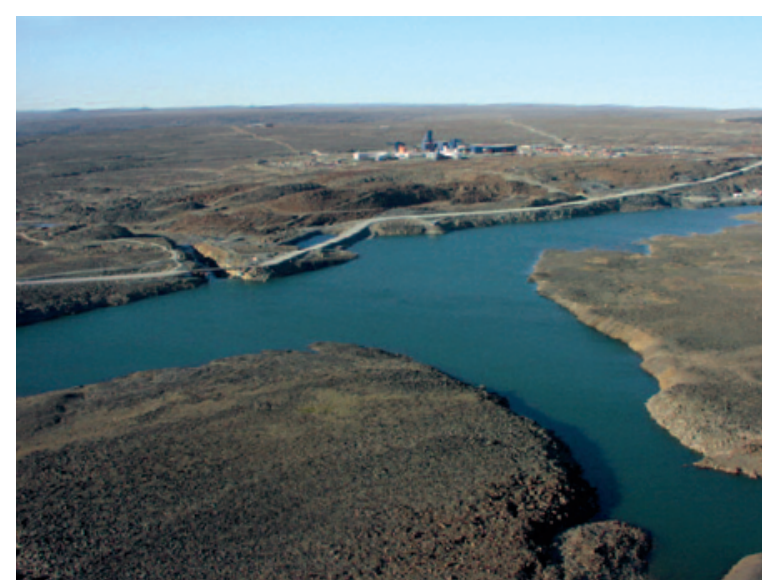

Figure 2. Raglan nickel-copper mine site in northern Québec, Canada, produces byproduct cobalt and platinum group elements, which are considered critical minerals. Photograph used with permission from Raglan Mine.

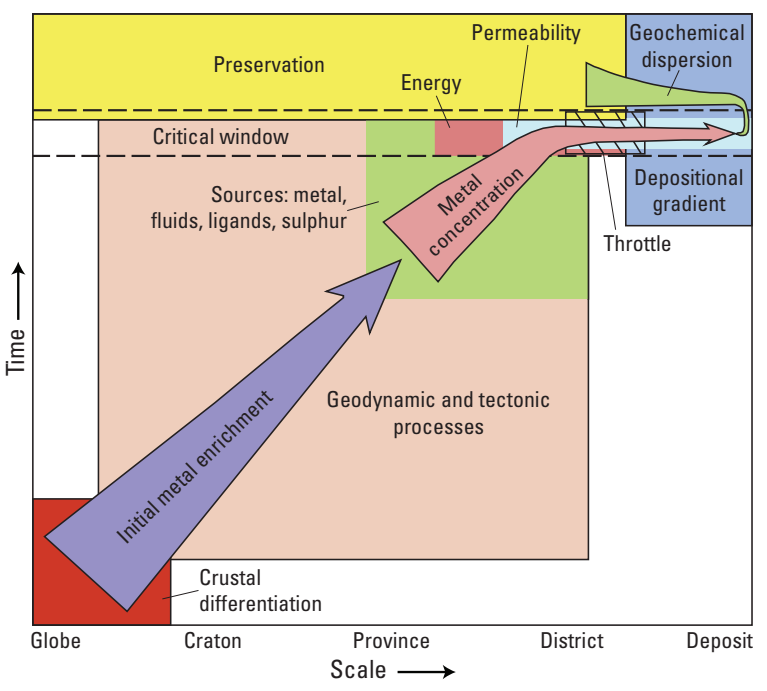

Figure 3. Spatial and temporal scales of mineral systems and their key geologic processes (modified from Huston and others, 2016).

\section{Critical Minerals Mapping Initiative (CMMI) GEOSCIENCE RESEARCH STREAMS

$\begin{aligned} & \text { 4. Communication (for example, } \\ & \text { outreach, workshops) }\end{aligned}$
3. Methods (for example, validation,
model exchange)

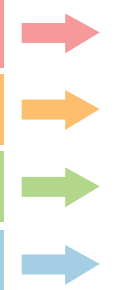 \\ OTHER STREAMS

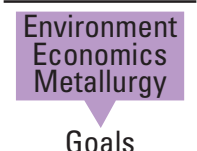 \\ - Improve data sharing - Identify areas having potential for additiona supplies \\ - Promote discovery}

\title{
Global Digital Database
}

The distribution of critical minerals in ore deposits is poorly understood. Geochemical analyses of archived collections are designed to inventory critical minerals (Granitto and others, 2020). Integration of the Ore Samples Normalized to Average Crustal Abundance database (OSNACA, http://www.cet.edu.au/research-projects/ special-projects/projects/osnaca-ore-samples-normalised-to-average-crustal-abundance) and other GA, GSC, and USGS databases will form the beginnings of a global database necessary to understand the controls on critical mineral distribution and to increase accuracy in mineral resource assessments.

\section{What Will be Gained Through Collaboration?}

\author{
Together GA, the GSC, and the USGS will:
}

- promote a collective understanding of critical minerals science;

- share data;

- identify knowledge gaps;

- unify critical minerals analyses from all three countries;

- build upon existing datasets for use in critical mineral assessments;

- improve the knowledge base of critical mineral concentrations in different deposit types; and

- leverage strengths to enhance working relationships and share expertise.

\section{Mineral Systems Approach}

The mineral systems approach to mineral deposit genesis provides a framework that considers geologic processes that control the formation and preservation of mineral deposits (fig. 3). Placing critical minerals into a mineral system framework represents one of the most important outcomes of knowledge and data sharing between the three geological survey organizations.

\section{Progress}

Workshops in July 2018 (Denver, Colorado, United States) and December 2019 (Ottawa, Canada) identified four geoscience streams of study as part of the CMMI (fig. 4); future workshops are proposed to advance this work.

\section{References Cited}

Granitto, M., Emsbo, P., Hofstra, A.H., Orkild-Norton, A.R., Bennett, M.M., Azain, J.S., Koenig, A.E., and Karl, N.A., 2020, Global geochemical database of critical minerals in archived mine samples: U.S. Geological Survey data release, https:// doi.org/10.5066/P9Z3XL6D.

Huston, D.L., Mernagh, T.P., Hagemann, S.G., Doublier, M.P., Fiorentini, M., Champion, D.C., Jaques, A.L., Czarnota, K., Cayley, R., Skirrow, R., and Bastrakov, E., 2016, Tectono-metallogenic systems-The place of mineral systems within tectonic evolution, with an emphasis on Australian examples: Ore Geology Reviews, v. 76, p. 168-210, accessed April 2020, at https://doi.org/10.1016/j.oregeorev.2015.09.005.

Labay, K., Burger, M.H., Bellora, J.D., Schultz, K.J., DeYoung, J.H., Seal, R.R., II, Bradley, D.C., Mauk, J.L., and San Juan, C.A., 2017, Global distribution of selected mines, deposits, and districts of critical minerals: U.S. Geological Survey data release, https://doi.org/10.5066/F7GH9GQR.

\section{For More Information Contact}

Geological Survey of Canada Natural Resources Canada 601 Booth Street Ottawa, Ontario K1A 0E8 Email: NRCan.tgi-igc.RNCan@ canada.ca
Geoscience Australia Sir Harold Raggatt Drive Symonston ACT 2609 Email: clientservices@ ga.gov.au
Mineral Resources Program U.S. Geological Survey 913 National Center Reston, VA 20192 Email: minerals@usgs.gov

Figure 4. Geoscience streams of CMMI.

Geoscience Australia has tried to make the information in this product as accurate as possible. However, it does not guarantee that the information is totally accurate or complete. Therefore, you should not solely rely on this information when making a commercial decision.

The GSC/Natural Resources Canada (NRCan) is not responsible for the accuracy or completeness of the information contained in the reproduced material. NRCan shall at all times be indemnified and held harmless against any and all claims whatsoever arising out of negligence or other fault in the use of the information contained in this publication.

Any use of trade, firm, or product names is for descriptive purposes only and does not imply endorsement by the U.S. Government.

Although this information product, for the most part, is in the public domain, it also may contain copyrighted materials as noted in the text. Permission to reproduce copyrighted items must be secured from the copyright owner. 